\title{
CROSS BORDER COOPERATION BETWEEN BOSNIA AND HERZEGOVINA AND SERBIA IN THE CASE OF TOURISM DEVELOPMENT IN MUNICIPALITIES OF MIDDLE PODRINJE
}

\author{
Senada Nezirović ${ }^{1}$ \\ Aida Bidžan-Gekić \\ Boris Avdić ${ }^{3}$ \\ Haris Gekić ${ }^{4}$
}

\begin{abstract}
It is widely recognized today that tourism with all of its impacts penetrates in every segment of social and economic development of many modern countries. Tourism has emphasized direct, indirect and multiplicative effects on economic development. That is the reason for increasingly high attention to him in a racent years, especially in the aspect of its contribution to comprehensible regional and national development. This paper object is the cross border cooperation between Bosnia and Herzegovina and Serbia in the case of tourism development in the municipal areas of Višegrad, Srebrenica, Bratunac and Zvornik on the Bosnian side of the border, and municipalities of Bajina Bašta, Ljubovija and Mali Zvornik on the eastern bank of Drina River (Serbian side). River Drina has central location in Western Balkans, hydrographically belonging to the drainage basins of Sava and Danube rivers. Its drainage basin connects areas of Eastern Bosnia and Western Serbia. The aim of this paper is tourism resources analysis and their delimitation between two countries. For the purpose of tourism resources delimitation, tourism-geographical and economic concepts are examined and used for determination of dominant motives. Guidelines for more effective coordination in the multiple mutual issues in the context of tourism development at the level of cross border cooperation, establishment of tourism destinations of mutual interests, as well as achievement of more effective comprehensible economic development of both countries are given in this paper.
\end{abstract} Keywords: tourism resources, tourism development, cross border cooperation.

\section{INTRODUCTION}

Considering integration processes in the South East Europe, European Union expansion, as well as aspirations of all countries in this region for its membership, cross border cooperation between Bosnia and Herzegovina with its neighbors represents very important factor of its political orientation. It is very understandable, because of its geocentral position within the region of Western Balkans. Among different contexts,

\footnotetext{
${ }^{1}$ Assistant Professor, Department of Geography, Faculty of Science, University of Sarajevo, Sarajevo, Bosnia and Herzegovina. e-mail: senadanezirovic@yahoo.com

${ }^{2}$ Senior Teaching Assistant, PhD, Department of Geography, Faculty of Science, University of Sarajevo, Sarajevo, Bosnia and Herzegovina. e-mail: aidabidzan@gmail.com

${ }^{3}$ Senior Teaching Assistant, Department of Geography, Faculty of Science, University of Sarajevo, Sarajevo, Bosnia and Herzegovina. e-mail: borisavdicpmf@hotmail.com

${ }^{4}$ Senior Teaching Assistant, PhD, Department of Geography, Faculty of Science, University of Sarajevo, Sarajevo, Bosnia and Herzegovina. e-mail: hgekic@gmail.com
} 
this ascertainment can be also applied to environmental issues. Environmental concerns are connected with ecological processes preservation, protection of cross border ecoregions and more effective control over mutual natural resources, that can effect development of tourism economy in the areas of local communities in the cross border regions. Research of these tourism resources in the one such region of Middle Podrinje within this paper demanded before the start the spatial definition, i.e. its delimitation on the both sides of the border. Motives and goals of this research are generally focused on the improvement of tourism development coordination on the levels of cross border cooperation, establishment of interest connections between tourism destinations, whole set of various developmental issues, and achieving higher efficacy of comprehensive economic development.

\section{RESEARCH METHODOLOGY}

This paper is based on theoretical and practical research of tourism development potentials in the towns close to Drina River within the region of Middle Podrinje, possibility of its valorization in tourism economy and cross border cooperation between Bosnia and Herzegovina and Serbia.

Methodology of this paper has demanded cabinet and field research. Tourism boards in the region have provided crucial help in the process of data collection. Beside spatial identification, fieldwork has included also a interviews with the representatives of tourism boards that are responsible for tourism resources promotion and development. For the purpose of cabinet research, adequate literature, planning documents, maps and statistical data are used, and analyzed through the geographical methods. This analysis is complemented with the data from strategic documents, which contains guidelines for economic development of this region.

\section{BASIC GEOGRAPHICAL CHARACTERISTICS OF PODRINJE}

Drina River is formed by the confluence of two other rivers - Piva and Tara, on the border between Bosnia and Herzegovina and Montenegro in the place called Šćepan Polje at the altitude of 433 meters. It has a meridional south - north direction, with the length of 346 kilometers, forming the natural border between Bosnia and Herzegovina and Serbia in the middle and lower part of its flow. Drina is the main river in eastern part of Bosnia and Herzegovina, as well as western part of Serbia. It is also the longest tributary of Sava River, to which it brings 11,7 billion of cubic meters of water annually. ${ }^{1}$ It is also worth of mentioning that Drina is fast and impetuous river. Rapidness and large amount of water boost process of its self-purification, so it can be classified into rivers of the better quality. Drina River valley generally has many

\footnotetext{
${ }^{1}$ Marić, R. (2002): Geodiverzitet sliva rijeke Drine, Zbornik radova, Geografski fakultet, Univerzitet u Beogradu, Beograd, pp. 59 -70.
} 
meanders that are placed between gravel and sand banks. ${ }^{1}$ In the lower part of the flow, many river islands are formed -27 of them are placed within the Zvornik Lake. On the other side, in upper regions, gorges and canyons can be found. Forests of ash, white willow, poplar and oak are densely distributed in these areas. Three hydropower plants are built on the Drina River, and because of that significant segments of its flow are turned into calm lake surface. The whole region of Drina River basin is called Podrinje, which can be divided into three sub-regions - Lower, Middle and Upper Podrinje.

Archeological findings indicate that the region of Middle Podrinje has been populated in a prehistoric period. Drina River has served as the central geographical object of Glasinac culture whose holders were the Autariatae tribes during the Bronze and Iron Age. These tribes were settled around the upper flow of Drina River, especially in the area of Piva and Tara confluence, including the surrounding valleys and highlands in northern Montenegro, southeastern Bosnia and western Serbia. Autariatae-Glasinac region on the territory of modern Bosnia stretched from Mount Romanija, across Glasinac plateau and Rogatica, through Drina River. East of Drina River in neighboring Serbia, this area was stretched across Mount Tara and Mount Zlatibor through Western Morava River, and through rivers Lim and Uvac in the south. ${ }^{2}$ Importance of settlement and resources in the Drina River basin was specifically emphasized at the end of 2nd century A. D. in the network of Roman roads in the Balkans, which were connecting the Drina valley with the Pannonia and Adriatic coast. In the region of Argentaria, Romans were constructing mines and towns that were alike to those on Italian peninsula. At numerous sites along Drina River, labels of town Malvesiatum have been found - near Skelani, Rudo, Stari Brod, Požega and Užice. ${ }^{3}$

Byzantine emperor Constantine VII Porphyrogenitus in 10th century stated that northern territory of his empire has been stretched from Bosnian land on the west to Rascia on the east. Podrinje was its central part. Priest of Duklja mentioned this region under the name Land of Drina. Through all historic periods, towns in the Drina valley have had an enormous significance in the context of communication and trade, as well as local natural resources exploitation.

\section{MUNICIPALITIES OF THE MIDDLE PODRINJE}

The Middle Podrinje region in the narrow sense comprises of seven municipalities. Four of them are located in Bosnia and Herzegovina - Višegrad, Srebrenica, Bratunac and Zvornik, while three of them belong to the Republic of Serbia - Bajina Bašta, Ljubovija and Mali Zvornik (Figure 1).

\footnotetext{
${ }^{1}$ COOR - Centar za okolišno održivi razvoj (2013): Studija o održivom korištenju i zaštiti prirodnih resursa u prekograničnom području Srbije i Bosne i Hercegovine, Općina Ljubovija. Katalogizacija u publikaciji Narodna biblioteka Srbije, Beograd.

${ }^{2}$ http://documents.tips/documents/autarijati.html (6th October 2016)

${ }^{3}$ Loma S. (2009): Municipuim Malve(n)siatium u svjetlu epigrafskih spomenika, Zbornik radova, Srebrenica, pp. 193-211
} 


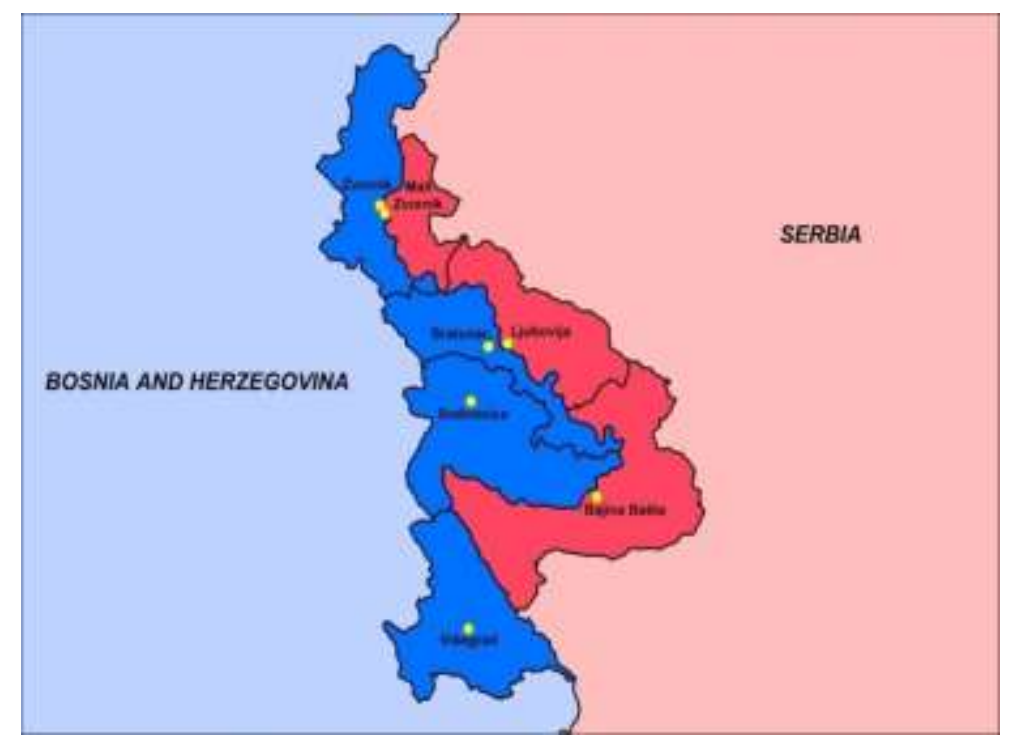

Fig. 1. Geographical position of towns and municipalities in Middle Podrinje (Author: Boris Avdić)

Municipality of Višegrad is located in southeastern part of Bosnia on the banks of Drina River. It has area of $447 \mathrm{~km}^{2}$, with a population of 10.688. Eastern boundary of municipality is at the same time national border of Bosnia and Herzegovina against Republic of Serbia, i. e. Municipality of Bajina Bašta, and City of Užice. On the south, Višegrad borders Rudo municipality, on the west Rogatica municipality, and on the north Srebrenica municipality. Višegrad has relatively good road connection with other cities in Bosnia and Herzegovina and Serbia.

That fact makes it an attractive transit tourism destination. Town of Višegrad is the administrative center of the municipality of the same name, and one of the most famous places in Eastern Bosnia, in the Podrinje region. It is located in the valley of Drina River, on the slopes of surrounding mountains, with the elevation of 1000 meters and more. Višegrad valley is one of the rare wider parts along the Drina River, which is usually followed with the narrow gorges and canyons. First mention of name Višegrad was in documents from the 13th century, for the settlement next to the fort of the same name. This forts remnants can be found on the hill above present-day town of Višegrad. During the 14th century, this territory was in position of the medieval nobleman Pavlović.

Ottomans have ruled this area from 15th century until 1878, when it was captured by Austro-Hungarian troops. In Kingdom of Yugoslavia, Višegrad was part of Drina Banovina. After World War II, Višegrad became one of numerous municipalities of the SR Bosnia and Herzegovina, within SFR Yugoslavia. According to Dayton Peace Agreement, which ended the last war, Višegrad belongs to the entity of Republika Srpska. 
Municipality of Srebrenica is places in the middle part of the Drina drainage basin. On $539 \mathrm{~km}^{2}$ of its territory live 13.409 people, according to the 2013 census. Southern municipality boundary is formed by the Drina River, and it is a part of national boundary between Bosnia and Herzegovina and Serbia. Intranational boundaries mainly go to the north and west, with the municipalities of Branica, Milići, Rogatica and Višegrad. Srebrenica is connected by roads with Zvornik, Bijeljina, Tuzla and Sarajevo, as well as with Bajina Bašta on the other side of Drina River. During the ancient times, it was important mining and trade center between the Roman provinces of Pannonia and Dalmatia. In the written sources, Srebrenica is mentioned under the current name first time in 1353. It was second most important silver mine on the Balkans, after the Novo Brdo in Serbia. Customs and coin mint were located here. ${ }^{1}$ Ottomans have ruled this area from 15 th century until 1878, when it was captured by Austro-Hungarian troops. In the Kingdom of Yugoslavia, Srebrenica was part of Drina Banovina. After World War II, Srebrenica became one of numerous municipalities of the SR Bosnia and Herzegovina, within SFR Yugoslavia. According to Dayton Peace Agreement, which ended the last war, Srebrenica belongs to the entity of Republika Srpska.

Municipality of Bratunac covers the plain and hilly terrain on the Drina Rivers left bank. Extreme point of Bosnia and Herzegovina national territory to the east is located here. It has an area of $293 \mathrm{~km}^{2}$ and population of 20.340 , according to 2013 census. North and east boundary toward the Serbia is formed by Drina River. Bordering municipalities to the south and west are Srebrenica, Milići and Bratunac.

Srebrenica has road connections with Zvornik, Tuzla, Bijeljina and Sarajevo, as well as with Ljubovija on the other side of Drina River. In recorded documents, first mention of Bratunac is traced back to 1381, when it was a small settlement on the road between medieval Bosnia and Serbia. Bratunac received status of separate municipality in 1927. After the last war in Bosnia and Herzegovina, it completely went to the entity of Republika Srpska.

City (municipality) of Zvornik is another administrative unit in the eastern bordering region of Bosnia and Herzegovina. It has an area of $387 \mathrm{~km}^{2}$, and the population of 58.856 (according to 2013 census). Eastern boundary is marked by the Drina River, and again, it is a part of international border between Bosnia and Herzegovina and Serbia. It also shares internal boundary with the municipalities of Bratunac, Milici, Vlasenica, Šekovići, Osmaci, Sapna, Ugljevik and Bijeljina. It is very well connected with Bijeljina, Tuzla and Sarajevo, as well as with neighboring Serbian town of Mali Zvornik, on the other side of Drina River. Its earliest record was in 1410. During the Ottoman period, it was important administrative center of the sanjak of the same name. Following periods, in Austro-Hungaria and Kingdom of Yugoslavia, Zvornik was figuring as developed economic center, especially in the sense of crafts and trade. In SFR Yugoslavia it became a separate municipality within Bosnia and Herzegovina. Currently, it is a part of Republika Srpska.

\footnotetext{
${ }^{1}$ According to Tourism Board of Srebrenica (2016).
} 
Municipality of Bajina Bašta is part of the Zlatibor District in Republic of Serbia. It covers an area of $673 \mathrm{~km}^{2}$, with the population of 26.022 (according to 2011 census). The biggest of western boundary toward Bosnia and Herzegovina is formed by the Drina River and Mount Zvijezda. Bordering municipalities in Serbia are: Ljubovija to the north, Kosjerić and Valjevo to the west, and Užice to the south. It is connected by Drina valley with Ljubovija, Loznica and other major centers in the north. Road connection with Bosnia and Herzegovina is dependant on the bridge next to village of Skelani. In the Roman period, Bajina Bašta firstly was part of the Illyria province, and than of Dalmatia province. This was important station on the road between Požega and Argentaria (Srebrenica). During the medieval times, it was a peripheral region of Rascia, but was also a stable part of Serbian state. After the Ottoman conquest of Serbia, this region became part of the nahiye of Soko, which was ceded to Zvornik Sanjak in 1480. In the following periods, Bajina Bašta has grew from a small rural settlement to a decent town. Status of municipality was given to Bajina Bašta in $1960 .{ }^{1}$

Municipality of Ljubovija is placed in the western Serbia, and iadministratively it is a part of Mačva district. It is somewhat smaller municipality than average, with an area of $356 \mathrm{~km}^{2}$ and population of 14.469 (according to 2011 census). Western border with Bosnia and Herzegovina is completely formed by the Drina River. It also borders municipalities of Mali Zvornik to the northwest, Krupanj and Osečina to the north, Valjevo to the east, and Bajina Bašta to the south. Its road connections are predeterminated by the Drina River valley. Across the bridge near Bratunac, it is connected with the territory of Bosnia and Herzegovina. During the Roman period, this area was part of the Dalmatia province, and the road between Argentaria and Singidunum was crossing through its. Romans have exploited local mines in Crnča. Through medieval times, Ljubovija was part of Byzantine Empire and Serbian state. Its current toponym was first recorded in 1319. Fortress of Soko and Crnča mines was very attractive to Ottomans too, so this area became part of its empire in 15th century. Ljubovija got the status of town in 19th century. Great flood in 1896 destroyed this settlement, and new one with the same name was constructed 3 kilometers upstream.

Municipality of Mali Zvornik is located in western part of Republic og Serbia. It has an area of only $184 \mathrm{~km}^{2}$ with population of 12.482 . This municipality is formed in 1955 , and it is one of the youngest and smallest mnicipalities in Serbia. Western municipal boundary is at the same time national border with Bosnia and Herzegovina (on the Drina River). Neighboring municipalities as Loznica to the north, Krupanje to the east, and Ljubovija to the southeast. Municipality of Mali Zvornik has favourable geographical position. It is located on the main road between Belgrade and Bajina Bašta, principal transport communication in Western Serbia. It is connected with Bosnia and Herzegovina through bridges on the Drina River (Zvornik and Karakaj).

${ }^{1}$ http://www.bbasta.org.rs/istorijat.html $\left(7^{\text {th }}\right.$ October 2016) 


\section{TOURISM RESOURCES IN MIDDLE PODRINJE}

Drina River is the most significant tourism resource in the whole region of Podrinje. Some other potentials in Middle Podrinje are related to nature reserve in the Trešnjica Canyon, where colony of griffon vultures can be found. This is located in the territory of Municipality of Ljubovija. Attractive mountains such as Tara, Javor and Sušica should also be mentioned. Slopes of these mountains are habitat of Serbian spruce (Picea omorika). This area is a unique landscape, where many endemic plant and animal species can be found. High value of its geo- and biodiversity contributes to the great tourism potential of Middle Podrinje, which is still now sufficiently valorized by Serbia and particularly Bosnia and Herzegovina. Table 1 shows these and many other tourism resources of Middle Podrinje.

Table 1. Tourism resources in tourism offer of the region of Middle Podrinje

\begin{tabular}{|c|c|}
\hline $\begin{array}{l}\text { Tourism resources in Bosnia and } \\
\text { Herzegovina }\end{array}$ & Tourism resources in Serbia \\
\hline $\begin{array}{l}\text { Višegrad } \\
\text { Natural tourism resources: Drina River } \\
\text { with reservoirs of Perućac and Višegrad, } \\
\text { thermal spa Vilina Vlas, hunting } \\
\text { grounds of Panos and Kamenica. } \\
\text { Historical objects: Mehmed-pasha } \\
\text { Sokolović bridge (built 1577) } \\
\text { Tourism infrastructure: hotel, three } \\
\text { motels, restaurants and cafe bars } \\
\text { Tourism offer: tourist train on the route } \\
\text { Višegrad-Mokra Gora, Andrićgrad. }\end{array}$ & $\begin{array}{l}\text { Bajina Bašta } \\
\text { Natural tourism resources: River Drina } \\
\text { canyon, Perućac and Zaovine Lakes, } \\
\text { Mount Tara. } \\
\text { Historical objects: prehistoric } \\
\text { archaeological sites, religious objects. } \\
\text { Tourism infrastructure: seven hotels, } \\
\text { restaurants and cafe bars. } \\
\text { Tourism offer: picnicking, congress and } \\
\text { sport tourism (Mount Tara), Drina regatta, } \\
\text { Most Fest rock festival. }\end{array}$ \\
\hline $\begin{array}{l}\text { Srebrenica } \\
\text { Natural tourism resources: Crni Guber } \\
\text { spa, Drina River canyons and gorges, } \\
\text { Perućac Reservoir, hunting ground of } \\
\text { Sušica, Serbian spruce natural reserve. } \\
\text { Historical objects: archaeological sites } \\
\text { of Roman towns of Argentaria and } \\
\text { Municipium Malvesiatium, medieval } \\
\text { forts, religious objects, Potočari } \\
\text { Memorial Center. } \\
\text { Tourism infrastructure: } \\
\text { house, two motels, restaurants and cafe } \\
\text { bars. } \\
\text { Tourism offer: kayaking, fishing, } \\
\text { hunting grounds, boating through Drina }\end{array}$ & $\begin{array}{l}\text { Ljubovija } \\
\text { Natural tourism resources: Drina River } \\
\text { with low banks, Soko mountains, Special } \\
\text { Nature Reserve Trešnjica River. } \\
\text { Historical objects: medieval town of } \\
\text { Soko. } \\
\text { Tourism infrastructure: two hotels, two } \\
\text { motels, restaurants and cafe bars. } \\
\text { Tourism offer: National Park Tara, } \\
\text { Vrhopolje ethno village, Drina regatta. }\end{array}$ \\
\hline
\end{tabular}




\begin{tabular}{|c|c|}
\hline canyon, Pančić regatta. & \\
\hline $\begin{array}{l}\text { Bratunac } \\
\text { Natural tourism resources: gravel } \\
\text { banks suitable for fishing, hunting } \\
\text { grounds of Glogova and Čauš. } \\
\text { Historical objects: archeological sites } \\
\text { and stećci tombstones. } \\
\text { Tourism infrastructure: hotel, two } \\
\text { motels, restaurants and cafe bars. } \\
\text { Tourism offer: fishing on the localities } \\
\text { of Bjelovac, Ljubovija Bridge and Plaža } \\
\text { Raj, camping, picnicking. }\end{array}$ & $\begin{array}{l}\text { Mali Zvornik } \\
\text { Natural tourism resources: Zvornik } \\
\text { Lake, Radalj Spa, Radalj Lake. } \\
\text { Historical objects: achaeological } \\
\text { localities, Roman forts, religious objects. } \\
\text { Tourism infrastructure: two hotels, } \\
\text { private accommodation, restaurants and } \\
\text { cafe bars. } \\
\text { Tourism offer: Radalj Spa, Radalj Lake. }\end{array}$ \\
\hline $\begin{array}{l}\text { Zvornik } \\
\text { Natural tourism resources: Zvornik } \\
\text { Lake, Vitinka mineral springs, } \\
\text { viewpoint of Divič, Topole beach. } \\
\text { Historical objects: remnants of Roman } \\
\text { mines and the querry. } \\
\text { Tourism infrastructure: hotel, two } \\
\text { motels, restaurants and cafe bars. } \\
\text { Tourism offer: Topole beach and } \\
\text { promenade, traditional Drina regatta } \\
\text { Zvornik-Šepak Bridge. }\end{array}$ & \\
\hline
\end{tabular}

\section{DELIMITATION OF TOURISM RESOURCES OF MIDDLE PODRINJE}

Tourism development possibilities in aforementioned municipalities of Middle Podrinje are based on rich natural, cultural and historical heritage. From the aspect of tourism geography, existing natural resources in the Drina River valley are solid foundation for the creation of tourism product (Figure 2), which is reflected in formation of tourism offer. Hydroaccumulation reservoirs on Drina River have more than 1.800 sunshine hours per year (250 hours in July) and they belong in the group of tourism resources with highly emphasized recreation characteristics. In such order, they represent the basis for development of swimming, boating, fishing and sports tourism in this region.

\footnotetext{
${ }^{1}$ Source: Tourism board of Zvornik (8th October 2016)
} 


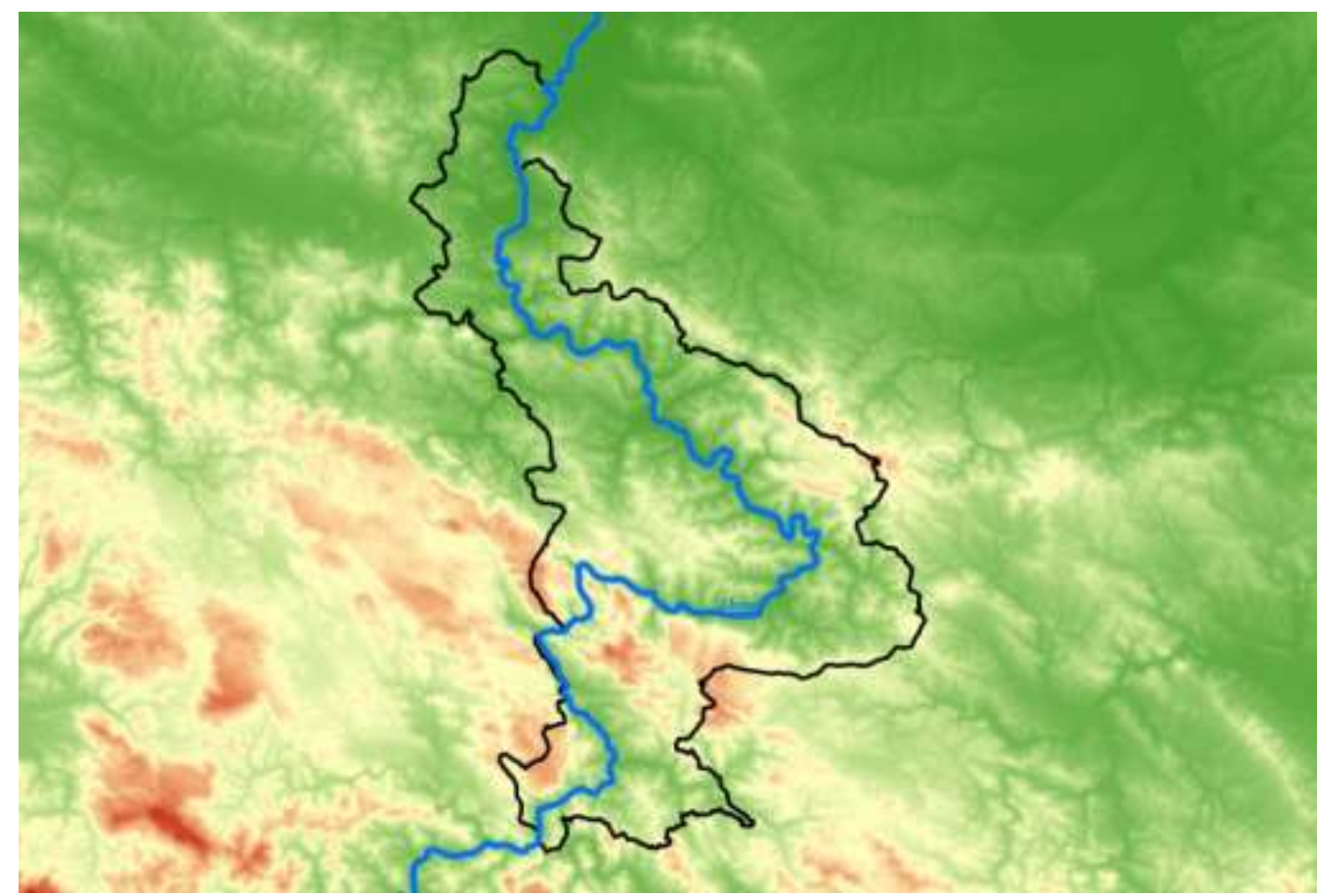

Fig. 2. Position of Drina River within the region of Middle Podrinje (Author: Boris Avdić)

Tourism significance of reservoirs (lakes) on the Drina River is reflected in the possibilities for numerous types of recreation, such as sport fishing, swimming and various other competitions. Besides recreation and swimming tourism, these reservoirs are suitable for water sports like sailing, rowing, or regatta. Rafting on the Drina River has a long tradition. Back in the past, for this activity were used wooden logs, and it have had an economic significance. ${ }^{1}$ As a memory on raftsmen, during summer rafting tourist routes down the Drina River are organized. One of the most effective way of promotion of the Drina River is manifestations that are called regatta. During the July and August, numerous vessels can be seen on the Drina River. Great interest is shown for these manifestations, as confirmed by the high number of participants.

In July, Bratunac regatta starts its slalom from bordering bridge in Skelani to Bratunac. In the beginning of August, Zvornik regatta starts form bordering bridge in Zvornik and goes downstream toward Bijeljina. Every year, there is more than 1000 participants in these activities. ${ }^{2}$ In July, municipal tourism boards of Srebrenica and Bajina Bašta organize manifestation under the name Pančić Regatta, which represent tourist voyage down the Drina River through its gorge. Regattas are accompanied by various events and last for several days. During that time, depending on the manifestation organizers

\footnotetext{
${ }^{1}$ Hasić, J. (1892): Privreda srebreničkog kraja. Srebreničke novine, No. 7, p. 56.

${ }^{2}$ Tourism Organization of Republika Srpska (2008): Drinska regata. Zvornik.
} 
participants enjoy various activities, such as camping on the river bank, socializing, fishing, swimming, bridge jumping, barbecue dinners and music festivals. (Table 2)

Table 2. Manifestations related to Drina River in the Middle Podrinje

\begin{tabular}{|l|l|}
\hline $\begin{array}{l}\text { Manifestations in Bosnia and } \\
\text { Herzegovina }\end{array}$ & Manifestations in Serbia \\
\hline $\begin{array}{l}\text { Višegrad } \\
\text { Drinski Kotlić; } \\
\text { Jušegrad Regatta; }\end{array}$ & $\begin{array}{l}\text { Bajina Bašta } \\
\text { Drina Regatta; } \\
\text { The Most Fest; } \\
\text { Festival of Rakija, Honey, Herbs and } \\
\text { Folklore. }\end{array}$ \\
\hline $\begin{array}{l}\text { Srebrenica Višegrad bridge. } \\
\text { Pančić Regatta. }\end{array}$ & $\begin{array}{l}\text { Ljubovija } \\
\text { Drina Regatta. }\end{array}$ \\
\hline $\begin{array}{l}\text { Bratunac } \\
\text { Škobaljijada; } \\
\text { Drina Slalom. }\end{array}$ & $\begin{array}{l}\text { Mali Zvornik } \\
\text { International Drina Regatta; } \\
\text { Somovijada; } \\
\text { Zvornik } \\
\text { Zvornik Summer; } \\
\text { Drina Regatta. }\end{array}$ \\
\hline
\end{tabular}

Drina gorge has special tourism value. Its length is 54 kilometers (from Višegrad to Bajina Bašta). The most attractive its segment is located between Mount Tara and Mount Sušica. Its depth reaches 1100 meters, while its bottom width is 100 meters. It has very steep and forested sides (Figure 3).

Drina River potential is a solid basis for creation of tourim offer in almost a year-long period. However, the focus is on the summer period between June and September (swimming, manifestations, water sports, sailing, fishing), and in extended sense on April, May and October (fishing competitions, gastronomy). Summer vaccation usually lasts between 5 and 7 days, while camping vacation next to the river of lakes last between a week and 2 weeks. The most frequent motives are sunbathing and relaxation in natural environment, accompanied with gastronomy and natural or cultural attractions. Considering total achieved results on the field of tourism development in the municipalities of the Middle Podrinje, it is stated that, except in environmental protection, there are no sufficient investment (with the exception of Bajina Bašta) in creation of new tourism contents that would improve economic situation in this region. For tourism valorization of this Drina River sector, adequate vessels are required. Although emphasized interest for tourism activities on the Drina River exists, lack of tourism capacities, spatial adaptability and tourism presentation is evident. ${ }^{1}$ As the fact

\footnotetext{
${ }^{1}$ Nezirović, S. (2006): Turizam kao faktor razvoja Srebrenice. PMF, Tuzla.
} 
that level of tourism infrastructure is crucial element of tourism valorization of existing resources, lack of it cause negative impact on total tourism development. Investment in tourism contents, infrastructure, as well as revitalization and expansion of accommodation capacities would bring an increase of economic benefits.

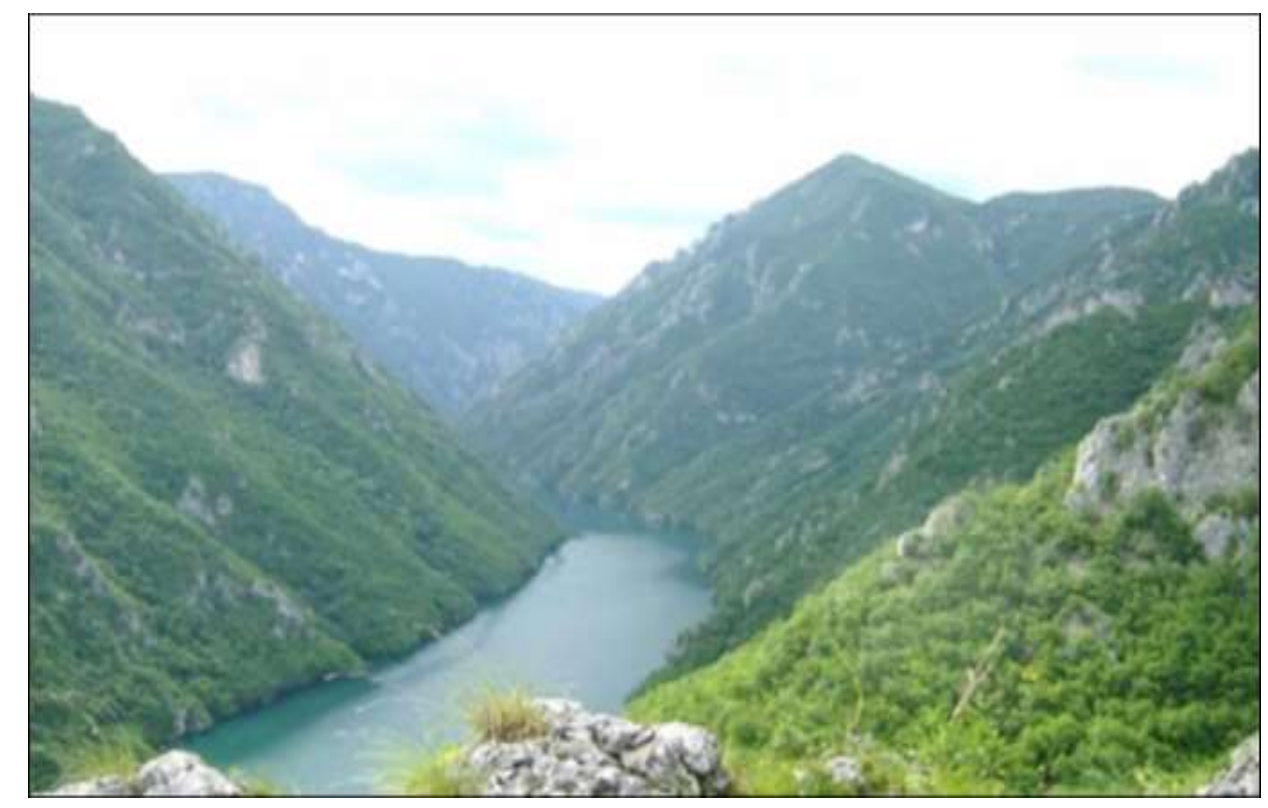

Fig. 3. The most attractive segment of Drina gorge

(Photo: Senada Nezirović)

Tourism is an economic branch, whose development in organizational context is backed by an environment, from the lowest to the highest levels of management and authorities. In order to that, it can be said that there are realistic possibilities for the development of tourism in aforementioned municipalities, and that it is justified to invest in this economic sector. That is why focus in these bordering areas should be given to tourism as a principal economic activity. It is necessary to improve institutional framework for development of small and medium enterprises, than to promote cross border cooperation and market accessibility, and to re-establish cross border synergy between tourism organization that contribute to development of tourism in order to make a progression in the area of mutual cooperative initiatives. It is evident that there is a lack of more significant interaction between local population on the both sides of the Drina River in the field of strengthening of cultural and sport connections, as well as of mutual involvement in the activities of local interest. Introduction of local cultural heritage to tourists contributes to bringing people together. Besides economic benefits and reduction of unemployment, one of the principal reasons for tourism development of this area is process of progress in inter-ethnic relations in this war-torn region. 
All aforementioned tourism activities require the cooperation between tourism boards in bordering regions on comprehensive promotion of tourism offer, which can be done through: Internet, TV shows, high-resolution videos, prospects and brochures in domestic and several languages, participation on regional and international fairs etc. These activities could increase the value of tourism destinations.

\section{FINDINGS AND DISCUSSION}

Starting with previously stated facts and the basic characteristics of tourism offer and demand, it can be concluded that tourism in this region did not receive satisfying status, and there are numerous serious deficiencies. Tourism development on the regional and national basis is directly related with developmental policies, structural plans, standards, institutional factors and other elements. Developmental measures, support programs, reduced taxes, stimulating financing measures, tourism and transport infrastructure and accommodation capacities are the factors required for successful tourism enterprising. In accordance with that, in the future period, there is a need for gathering of all representatives of local tourism boards and tourism business in order to promote cross border cooperation in the tourism area, and using of human, natural, cultural and economic resources.

For the continuation of tourism and general economic development, it is necessary to reduce relative isolation of the study area, as well as to build a stronger institutional network of human resources and capacities. Bosnia and Herzegovina, as well as neighboring Serbia, goes through final transitional reforms and faces the problems such as high rate of unemployment, insufficient stimulative environment and massive grey economy. On the basis of these statements, it is of crucial importance that the two countries analyze their current position, recognize the need for modeling their future and take strategic control of its key economic resources. Great potential of Drina River and insufficiently used possibilities for cross border cooperation should encourage ideas about projects that will contribute to the economic development in the wider area of Podrinje. That is particularly referred to a tourism, through establishment and development of partnership on local, regional and international level.

\section{REFERENCES}

1. Bratunac Municipal Archive (2008). Department for Social Activities, Bratunac.

2. Centar za okolišno održivi razvoj (2013): Studija o održivom korištenju i zaštiti prirodnih resursa u prekograničnom području Srbija-Bosna i Hercegovina, Općina Bratunac.

3. COOR - Centar za okolišno održivi razvoj (2013): Studija o održivom korištenju i zaštiti prirodnih resursa u prekograničnom području Srbije i Bosne i Hercegovine, Municipality of Ljubovija. Katalogizacija u publikaciji Narodna biblioteka Srbije, Belgrade. 
4. Handžić, A. (1975): Tuzla i njena okolina uXVI vijeku, Svjetlost, Sarajevo.

5. Hasić, J. (1892): Privreda srebreničkog kraja. Srebreničke novine, No. 7.

6. Đurđević, M. (2009): Rimske terme u unutrašnjosti Balkana, Zbornik radova, Narodna biblioteka Srebrenica.

7. Popis stanovništva, domaćinstava i stanova u Bosni i Hercegovini (2013). Agencija za statistiku Bosne i Hercegovine, Sarajevo.

8. Loma S. (2009): Municipuim Malve(n)siatium u svjetlu epigrafskih spomenika, Zbornik radova, Srebrenica Službeni glasnik RS, No. 104/09 i 24/11.

9. Marić, R. (2002): Geodiverzitet sliva rijeke Drine, Zbornik radova, Geografski fakultet, Univerzitet u Beogradu, Belgrade.

10. Nezirović, S. (2006): Turizam kao faktor razvoja Srebrenice. PMF, Tuzla.

11. Strategija razvoja turizma u Gornjem Podrinju (2007), Institut za građevinarstvo IG, Banja Luka.

12. Tourism Board of Bajina Bašta (2016).

13. Tourism Board of Srebrenica (2016).

14. Tourism Board of Višegrad (2016).

15. Tourism Board of Zvornik (2016).

16. Tourism Organization of Republika Srpska (2016).

17. http://asinfo.info/drinska-regata (10th October 2016)

18. http://www.bbasta.org.rs/istorijat.html (7th October 2016)

19. http://documents.tips/documents/autarijati.html (6th October 2016) 